Studia Judaica 23 (2020), nr 1 (45), s. 75-109

doi:10.4467/24500100STJ.20.003.12917

Hanna Kozińska-Witt (iD https://orcid.org/0000-0003-1806-8305

\title{
Unwarranted Notoriety? The Ritter Trials, 1882-1886*
}

\begin{abstract}
Moses and Gitla Ritter were accused of murdering the charwoman Franciszka Mnichówna. The accusation and trials which followed revoked the blood libel. In three circumstantial trials (1882-1886), despite the lack of evidence, the Ritters were found guilty and sentenced to death. Owing to the "ritual" nature attributed to the presumed murder, the trials became media events, followed by an international audience. The author discusses the course of the trials, considering whether and how the municipalities in which they took place exploited their unexpected popularity for promotional purposes. What importance did the urban elites attach to the trials? How can we interpret the three guilty verdicts, and what symbolic significance can be assigned to them?
\end{abstract}

Keywords: blood libel, trials, Galicia, the nineteenth century, press reports.

Słowa kluczowe: oskarżenie o popełnienie mordu rytualnego, procesy, Galicja, dziewiętnasty wiek, doniesienia prasowe.

\section{Introduction}

Before noon on 17 April 1886, Moses (Mojżesz) Ritter and his wife Gitla left Cracow for their home town of Lutcza, a village in the Strzyżów district near Rzeszów. ${ }^{1}$ At the railway station, a crowd of the Ritters' fellow Jews from Kazimierz bid them a respectful farewell. On the surface, the couple seemed to be unremarkable representatives of the "Jewish peasantry," living off agriculture and factoring in a dilapidated village, and so the

* This article was written for project no. 2015/19/P/HS3/04054 in programme Polonez 1 organized by National Science Center which received funding from the European Union's Horizon 2020 research and innovation programme under Marie Skłodowska-Curie grant agreement no. 665778 .

1 "Kronika," Nowa Reforma [henceforth: NR] 5 (1886), 63:3. 
particular reverence displayed toward them might seem surprising. What set the Ritters apart, though, were the three death sentences handed to them by the Galician courts. On each occasion, the couple's defense counsel appealed the sentences, which were subsequently quashed by the higher authorities in Vienna. Ultimately, the Ritters were found not guilty by the Vienna Supreme Court, and spared execution. The trials revived suspicions that Jews were guilty of practising ritual murder, and became a hot topic in the press as well as the focus of public interest abroad. The trials and revocations of the sentences in Vienna compounded the perception of Galicia as an "exotic"-in a negative sense-backward region. ${ }^{2}$ They also acted to solidify the developing modern antisemitism, facilitating the integration of characteristics of traditional Judeophobia and modern politics. For a time, the Ritter affair was very popular; among those to become involved was the Floridsdorf Rabbi Joseph Samuel Bloch, ${ }^{3}$ a member in the Viennese Parliament and of the Polish Club there. In summer 1883, Bloch accused the main advocate of arguments linking Jews with ritual murders, Prague University professor August Rohling, of forgery caused by incompetence. The charges were proved, and Bloch won the trial. Rohling's accusations of Jews and the Bloch-Rohling trial were widely discussed in the European press. ${ }^{4}$ According to Tim Buchen, an expert on Galician antisemitism, Bloch was the first to oppose the charges leveled at Jews by antisemites in a modern fashion, exposing their tactics and manipulation of public opinion. ${ }^{5}$ This Central European context was important for the "Ritter affair," as it led to its notoriety and ensured that the trial ceased to be perceived as against an individual, instead being seen as an attack on all Jews. ${ }^{6}$ This angle is also adopted

2 “Unser Österreich,” Neuzeit 26 (1886), 10:1; Tim Buchen, “'Herkules im antisemitischen Augiasstall' - Joseph Samuel Bloch und Galizien in der Reaktion auf Antisemitismus in der Habsburger Monarchie," in Ulrich Wyrwa (ed.), Einspruch und Abwehr: Die Reaktion des europäischen Judentums auf die Entstehung des Antisemitismus (1879-1914) (Frankfurt, 2010), 198f. For perception of Galicia in the Austrian press see: Hans-Christian Maner, Galizien: Eine Grenzregion im Kalkül der Donaumonarchie im 18. und 19. Jahrhundert (München, 2007), 206-221.

${ }_{3}^{3}$ Joseph S. Bloch, Erinnerungen aus meinem Leben (Wien-Leipzig, 1922), https://archive.org/details/erinnerungenausm00blocuoft [retrieved: 17 Apr. 2018]; id., Professor Rohling und das Wiener Rabbinat oder "Die arge Schlemmerei" (Wien, 1882).

${ }^{4}$ Bloch, Erinnerungen, 59-76, 81-158.

${ }^{5}$ Buchen, “'Herkules'," 193f.

6 "Noch gibt es Richter in Österreich,” Neuzeit 26 (1886), 11:1-2. The article quoted Neue Freie Presse. 
by scholars, including Simon Dubnow, while discussing occasions when Jews were accused of ritual murders. ${ }^{7}$

Something of a divide exists in recent historiography: no mention is made of the Ritter affair either in the works of Polish authors on the history of Galicia and Cracow, ${ }^{8}$ or those on the history of Galician judiciary. ${ }^{9}$ The only scholars to mention the case are those discussing the history of Jews ${ }^{10}$ and antisemitism: Jolanta Żyndul and Maria Cieśla ${ }^{11}$ refer to it at the greatest length, while Marcin Sobon,,${ }^{12}$ Maciej Moszyński, ${ }^{13}$ Alina Cała, ${ }^{14}$ Daniel Unowsky ${ }^{15}$ all make references, and Tim Buchen covers it in depth. ${ }^{16}$ Rachel Manekin also writes about the Ritters in her discussion of antisemitism in Galicia in The YIVO Encyclopedia of Jews in Eastern Europe. ${ }^{17}$ In recent times, the sensational nature of the affair has also been noted, and it is even cited in studies on Victorian culture, compared to Jack the Ripper. ${ }^{18}$

7 Simon Dubnow, Weltgeschichte des Jüdischen Volkes (Berlin, 1929), 10:91-92.

${ }^{8}$ E.g., Stanisław Grodziski, W królestwie Galicji i Lodomerii (Kraków, 2005); Marek Derwich (ed.), Pod zaborami 1795-1914 (Warsaw-Wrocław, 2005); Marian B. Michalik et al. (eds.), Kronika Krakowa (Warsaw, 1996); Stanisław Salmonowicz, Janusz Szwaja, Stanisław Waltoś, Pitaval krakowski (Kraków, 2010).

9 Jakub Kotliński, Tomasz J. Kotliński, Sądownictwo powszechne w Galicji w latach 1855-1918 (Jarosław, 2016).

${ }^{10}$ Filip Friedmann, "Dzieje Żydów w Galicji (1772-1914)," in Ignacy Schiper, Aryeh Tartakower, Aleksander Hafftka (eds.), Żydzi w Polsce odrodzonej. Działalność społeczna, gospodarcza, oświatowa i kulturalna (Warsaw, 1932), 394.

${ }^{11}$ Maria Cieśla, Jolanta Żyndul, "Sprawa Ritterów. Aktualizacja legendy mordu rytualnego w Galicji końca XIX wieku," in Grażyna Borkowska, Magdalena Rudkowska (eds.), Kwestia żydowska w XIX wieku. Spory o tożsamość Polaków (Warsaw, 2004); Jolanta Żyndul, Kłamstwo krwi. Legenda mordu rytualnego na ziemiach polskich $w$ XIX $i$ XX wieku (Warsaw, 2011).

12 Marcin Soboń, Polacy wobec Żydów w Galicji doby autonomicznej w latach 1868-1914 (Kraków, 2011), 93f.

${ }^{13}$ Maciej Moszyński, Antysemityzm w Królestwie Polskim. Narodziny nowoczesnej ideologii antyżydowskiej (1864-1914) (Poznań, 2017), 205f.

${ }_{14}$ Alina Cała, Żyd - wróg odwieczny? Antysemityzm w Polsce i jego źródła (Warsaw, 2012), 259, 269.

${ }_{15}$ Daniel Unowsky, The Plunder: The 1898 Anti-Jewish Riots in Habsburg Galicia (Stanford, 2018), 76f.

${ }^{16}$ Tim Buchen, Antisemitismus in Galizien: Agitation, Gewalt und Politik gegen Juden in der Habsburgermonarchie um 1900 (Berlin, 2012).

${ }^{17}$ Rachel Manekin, "Galicia," trans. Deborah Weissman, in The YIVO Encyclopedia of Jews in Eastern Europe, http://www.yivoencyclopedia.org/article.aspx/Galicia [retrieved: 19 Jan. 2018].

${ }^{18}$ Paul Begg, Jack the Ripper: The Facts (New York, 2013); Spiro Dimolianis, Jack the Ripper and Black Magic: Victorian Conspiracy Theories, Secret Societies and the Supernatural Mystique of the Whitechapel Murders (Jefferson, 2011), 51-53. 
Additionally, the case inspired a short crime film (Belle Epoque, part 2), and Adam Węgłowski used it as the basis of a 2012 crime novel. ${ }^{19}$

There are many works discussing the phenomena of the blood libels, their particular contexts, the accusations of Jews, technics of sensationalizing the trials which followed them, Galician antisemitism and myths concerning blood. ${ }^{20}$ In this article I prefer to take a different path and concentrate on how cities which "hosted" trials used them to promote themselves. This problem was addressed shortly by Barnet Hartston in the part of his book where he discusses blood libel trials in Imperial Germany. ${ }^{21}$ The questions which I ask here are: did urban elites of these cities thought that the trail notoriety could be used to promote the cities, and if yes, how? What impact did the Ritter trials have on Polish public opinion, and in particular what role did they play in Galicia, and especially Cracow, where the last two trials were held after transfer from Rzeszów? Did the trials, in which representatives of the Cracovian elite took part, change the city to some degree? How was the affair remembered in the immediate aftermath of the trials and in subsequent years? The analysis of how the trails were perceived and reported on will help me to answer these questions.

Unfortunately, court files have not survived, so I am reliant on press sources. I analyzed Cracow dailies ${ }^{22}$ : the conservative $\mathrm{Czas},{ }^{23}$ liberal Nowa Reforma; Lviv ones: the official Gazeta Lwowska, liberal Dziennik Polski; and the provincial press: Przeglad Rzeszowski and Kuryer Rzeszowski (both from Rzeszów), Unia (Tarnów), the Viennese Die Neuzeit, Österreichische Wochenschrift (or Dr. Blochs Österreichische Wochenschrift); as well as sporadically other periodicals. It is important to note from the outset that

19 Adam Węgłowski, Przypadek Ritterów (Katowice, 2012).

${ }^{20}$ E.g., Hanna Węgrzynek, "Czarna legenda” Żydów. Procesy o rzekome mordy rytualne $w$ dawnej Polsce (Warsaw, 1995). See one of the last works: Eugene M. Avrutin, Jonathan Dekel-Chen, Robert Weinberg et al. (eds.), Ritual Murder in Russia, Eastern Europe, and Beyond: New Histories of an Old Accusation (Bloomington, 2017); I am grateful to François Guesnet for this bibliographical information. For significance of myths concerning blood see: Joanna Tokarska-Bakir, Legendy o krwi. Antropologia przesądu (Warsaw, 2008); Żyndul, Kłamstwo krwi. The approach of Barnet Hartston was very helpful, see Barnet Hartston, Sensationalizing the Jewish Question: Anti-Semitic Trials and the Press in the Early German Empire (Leiden-Boston, 2005), 129-188; I am grateful to Agnieszka Jagodzińska for this bibliographical information.

21 Ibid., 142.

22 On Galician dailies, see Jerzy Myśliński, “Typologia,” in Jerzy Łojek (ed.), Prasa polska w latach 1864-1918 (Warsaw, 1976), 121-126.

23 “Sprawy sądowe. Morderstwo skrytobójcze," Czas 35 (1882), 283:2-4. 
the provincial press "blossomed" only in 1884, and thus was most useful for analyzing the second and third Cracow trials. ${ }^{24}$

\section{Annus horribilis?}

There are many indications that 1882, the year of the first trial, was a watershed moment in the history of antisemitism. This was also the time of the accusation of blood libel in Tiszaeszlár in Hungary, ${ }^{25}$ which was covered at length by the press, including Czas in Cracow. ${ }^{26}$ This had a major effect on exposure of the Ritter case. Not long before, pogroms took place in Russia, leading to the defection and increased presence of Jewish refugees throughout Galicia, especially in Brody. ${ }^{27}$ There were fears, including in Cracow, which lay on the main refugee route, that some would manage to settle in Galicia, and efforts were made to prevent this from happening. In 1882, the first antisemitic congress met in Dresden, an event that featured heavily in the press. ${ }^{28}$ In the Regional Assembly, Teofil Merunowicz, one of the first Galician antisemites, hurled accusations at Jews, ${ }^{29}$ deftly weaving the Ritter affair into his broader argument. ${ }^{30}$

${ }^{24}$ Konrad Meus dates the revival of the Polish provincial press to the period of 1880 1910. See Konrad Meus, "Prasa prowincjonalna w badaniach nad miastami galicyjskimi doby autonomicznej. Geneza - charakterystyka -interpretacja," in Kazimierz Karolczak, Konrad Meus (eds.), Prasa w warsztacie badawczym historyka (Kraków, 2017), 63.

${ }^{25}$ Hillel J. Kieval, "Tiszaeszlár," in The YIVO Encyclopedia of Jews in Eastern Europe, 2010, https://yivoencyclopedia.org/article.aspx/Tiszaeszlar_Blood_Libel [retrieved: 20 Apr. 2018]. Ulrich Wyrwa notes that antisemites instrumentalized this issue to organize a Europewide antisemitic movement; see: Ulrich Wyrwa, Die Internationalen Antijüdischen Kongresse von 1882 und 1883 in Dresden und Chemnitz: Zum Antisemitismus als europäischer Bewegung, https://www.europa.clio-online.de/essay/id/fdae-1481 [retrieved: 20 Jan. 2018]; "Dresden," Neuzeit 22 (1882), 37:313. Alternatively Tiszaeszlár was transcribed as Tisza Eszlár.

${ }_{26}$ Andrzej Żbikowski, Żydzi krakowscy i ich gmina w latach 1869-1919 (Warsaw, 1995), 280.

27 Ibid., 239f., 280.

${ }^{28}$ Such congresses were also supposed to contribute to a supranational consolidation of antisemitism, but even at national level it proved impossible to establish one uniform organization; Wyrwa, Die Internationalen Antijüdischen Kongresse.

29 As a Regional Assembly deputy, Teofil Merunowicz (1846-1919) worked for regulation of rivers, peasant loans, people's education, etc. He first submitted a petition suggesting that Jewish religious law contradicted Austrian state law in the Vienna Imperial Council in 1879. See Andrzej Żbikowski, Dzieje Żydów w Polsce. Ideologia antysemicka 1848-1914. Wybór tekstów źródłowych (Warsaw, 1994), 22-24.

${ }^{30}$ Teofil Merunowicz's suggestion that the Jewish religion permits ritual killings, 14 Sept. 1882 (excerpt from speech in the Galician Assembly), in ibid., 28; Moszyński, Antysemityzm w Królestwie Polskim, 205. In support of his arguments, Merunowicz cited the 
Merunowicz, who believed that murder had been carried out with the sanction of the Talmud, demanded that the book be translated in order to prove its destructive message, and also called for limitations on Jewish influences, e.g. by reforming the legal situation of religious communities to strip them of their autonomy. ${ }^{31}$

Although Merunowicz frequently cited Rohling in support of his arguments, he distanced himself from the suspicions that he might have had common goals with "foreign" antisemites (Stoecker, Henrici, Istoczy). ${ }^{32}$ He claimed that he was not motivated by anti-Jewish slogans, but by the need for amendments to the law. ${ }^{33}$

opinion of the Vienna rabbinate, with the result that the Lwów Community Council and Rabbi Löwenstein sent a telegram to the Vienna rabbinate. On behalf of the rabbinate, Dr. Güdemann replied: "Die Behauptung des Abgeordneten Merunowicz ist gänzlich erfunden"; "Kleine Chronik," Neuzeit 22 (1882), 38:320; also "Ostatnie wiadomości," Czas 35 (1882), 212:3. The Vienna rabbinate (signed as Dr. Güdemann, Rabb. Jacob Fleissig, Rabbinats-Assesor, Isak Tonelis Heindl Rabb.-Assesor, Rud. Fuchs Rabb.-Sekräter) explained to Marshal of the Sejm Krajowy, Mikołaj Zyblikiewicz, that the rabbinate did not offer any opinions in this regard, recommend any Jewish religious books, or excuse murder; see Sprawozdanie stenograficzne z rozpraw galicyjskiego Sejmu krajowego [henceforth: Sprawozdanie]. 10. posiedzenie 5. sesyi IV. peryodu Sejmu galicyjskiego z dnia 21 września 1882, p. 132, https://jbc.bj.uj.edu.pl/dlibra/publication/8727/edition/4492/content?ref=desc [retrieved: 18 Aug. 2018]; “Sejm. Sprawozdania sejmowe,” Czas 35 (1882), 217:1. Merunowicz was forced to admit that the Vienna rabbinate's writings did not make any mention of murder, but only of Caesarean sections on a dead woman; see "Korespondencya Czasu. Sejm," Czas 35 (1882), 232:3.

${ }^{31}$ Sprawozdanie. 6. posiedzenie 5. sesyi IV. peryodu Sejmu galicyjskiego z dnia 14 września 1882, p. 66, https:/jbc.bj.uj.edu.pl/dlibra/publication/8722/edition/4471/content?\&ref=desc [retrieved: 18 Aug. 2018]. "Wniosek p. Merunowicza o rewizji ustaw względem stosunków prawnych ludności wyznania mojżeszowego," in Sprawozdanie. 4. posiedzenie 5. sesyi IV.peryodu Sejmu galicyjskiego z dnia 11 września 1882, p. 30, https://jbc.bj.uj.edu.pl/dlibra/publication/8720/edition/4469/content?\&ref=desc [retrieved: 18 Aug. 2018]; Andrzej Żbikowski, "Rozwój ideologii antysemickiej w Galicji w II połowie XIX w.: Teofila Merunowicza atak na żydowskie kahały,” Biuletyn Żydowskiego Instytutu Historycznego 169-171 (1994), 21-39. Merunowicz's motion was supported, among others, by Cracovian conservative politicians Stanisław Tarnowski and Henryk Wodzicki. Merunowicz proposed that the Sejm set aside a credit amounting to 1,500 gulden for translation of the Talmud in the regional budget for the regulation of the Academy of Sciences in Kraków; see Teofil Merunowicz, Siedem próśb wniesionych do Wysokiego Sejmu Krajowego galicyjskiego w sesyi z roku 1880 w sprawie równouprawnienia Żydów (Lwów, 1880), 8; id., Żydzi. Studyum społeczne (Lwów, 1879), 211. Warschauer refers to a figure of 10,000 złr.; cited in Żbikowski, Dzieje Żydów w Polsce, 41.

${ }^{32}$ Merunowicz, Żydzi. Studyum społeczne, 90f., 211; Sprawozdanie. 6. posiedzenie 5. sesyi IV. peryodu Sejmu galicyjskiego z dnia 14 września 1882, p. 63.

33 Sprawozdanie. 22. posiedzenie 5. sesyi IV. peryodu z dnia 10 października 1882, p. 433, https://jbc.bj.uj.edu.pl/dlibra/publication/8746/edition/4527/content?\&ref=desc [retrieved: 18 Aug. 2018]. 
In the same year, a local "Jewish affair" was played out in Cracow, which may have helped to make antisemitism fashionable in the city. In a speech inaugurating the academic year at the Academy of Fine Art (16 October 1882), the respected painter Jan Matejko attacked Jewish students, accusing them of materialism, a lack of ideals and failure to embrace the national idea. ${ }^{34}$ The key moment in the "Matejko affair" was the court trial, during which the painter's legal counsel Dr. Józef Mochnacki gave a decidedly antisemitic speech, which he then published as a pamphlet at his own cost. ${ }^{35}$ Matejko developed his views further in the fourth issue of the antisemitic periodical Rola. For the Warsaw-based Izraelita, the Cracovian Mochnacki and Merunowicz from Lviv embodied the quintessence of Galician antisemitism. ${ }^{36}$

\section{Site and actors}

The site of the murder was a small village Lutcza on the postal road from Strzyżów. These parts of Galicia were regarded as very superstitious, a picture emphasized in the media, which portrayed a manicheistically divided world inhabited either by the dim and unenlightened peasantry or by the bright, enlightened residents of cities. The press frequently reported rumors spreading in the countryside which could lead to dangerous acts. ${ }^{37}$

The Ritters were rather well liked in the village, described by Dziennik Polski as benevolent and supporting the poor ${ }^{38}$ :

${ }^{34}$ Dariusz Konstantynów, “'Mistrz nasz Matejko’ i antysemici,” Kwartalnik Historii Żydów (2007), 2:164-198; Jarosław Krawczyk, Matejko i historia (Warsaw, 1990), 189-191, 204; Żbikowski, Żydzi krakowscy i ich gmina, 280f. For Jan Matejko's speech see: id., Dzieje Żydów w Polsce, 119-121.

${ }^{35}$ [Józef Mochnacki], Rozprawa w procesie karnym Jana Matejki przeciw p. Dr. L. E. [Leon Eibenschütz] o przestępstwo obrazy czci przeprowadzona w c.k. sadzie karnym w Krakowie, dnia 2-go grudnia 1882 (Kraków, 1883). The correspondent of the Warsawbased Tygodnik Illustrowany defended Matejko ardently, accusing the Kraków Jewish intelligentsia of oversensitivity; "Korespondencya Tygodnika Illustrowanego," Tygodnik Illustrowany (1883), 364:388. "Sprawy sądowe. Obraza czci," Czas 35 (1882), 278:2; "Kronika," Czas 35 (1882), 279:2; "Sprawy sądowe," Czas 35 (1882), 280:3; "Sprawy miejskie," Czas 35 (1882), 282:2.

${ }^{36}$ Whereas much was written about Merunowicz, Józef Mochnacki remains a littleknown figure. All I was able to learn about him is that he was a city councillor.

${ }^{37}$ On this susceptibility to superstitions see: Przeglad Rzeszowski 4 (1886), 8:5; "Z izby sądowej," Kuryer Rzeszowski 4 (1886), 6:9. Tim Buchen underlines critically the tendency to emphasize the superstitiousness of the local residents.

38 "Sprawy sądowe," NR 1 (1882), 14:3; and NR 1 (1882), 19:3. 
Ritter lived in Lutcza like his father and his father before him, and never worked in liquor sales, but only in agriculture, living in his cottage and 10 morgens of his own land. He cannot read or write. He has been punished several times. ${ }^{39}$

The Ritters were Orthodox Jews, but not Hasidim. They all spoke fluent Polish, and their daughters even recorded dates according to Catholic holidays. ${ }^{40}$ A photograph of Gitla and Moses Ritter taken in Szymon Balicer's studio in Cracow presents the couple sitting at an intricately carved table, both in coats, Gitla in a headscarf, and the bearded and sidelocked Moses wearing a yarmulke. ${ }^{41}$ Judging by this photograph, the Ritters' appearance was similar to that of most Galician Jews. ${ }^{42}$ During the trial, Ritter's licentiousness and immoral conduct were referred to, a suggestion not corroborated by the reference provided for him by the community council. ${ }^{43}$ Ritter's neighbor and alleged accomplice Marceli Stochliński was assessed very negatively. He was a previously convicted drunk, rapist and thief; according to the Lutcza parish priest Jan Drzewicki, "the worst individual in the whole parish." 44 Stochliński was the Ritters' nearest neighbor, and since he was a bad proprietor and drunkard, he had steadily sold off his inherited land: "Once wealthy, he lost his land to the Jews," as Lutcza's village mayor put it. ${ }^{45}$ The Jews in question were Ritter and his brother-in-law. ${ }^{46}$ Nonetheless, Stochliński continued to live alongside Jews, "and would even jabber away in Yiddish." ${ }^{47}$ Yet he was convinced that "if you live with the Jews, you die by the Jews," and was aware of the impropriety of his communing with the Jewish population.

39 “Z izby sądowej,” Dziennik Polski 15 (1882), 284:2.

40 "Sprawy sądowe. Morderstwo skrytobójcze, Rzeszów, 12 grudnia," Czas 35 (1882), 285:2-3.

${ }^{41}$ Photograph from the collection of the Jüdisches Museum in Wien; see Gabriele Kohlbauer-Fritz (ed.), Zwischen Ost und West: Galizische Juden und Wien. Ausstellungskatalog (Wien, 2000), 145.

42 "Proces Rittera," Gazeta Lwowska 72 (1884), 226:4; "Sprawy sądowe, Rzeszów, 12 grudnia. Morderstwo w Lutczy," NR 1 (1882), 12:3.

${ }_{43}$ On the tendency to sexualize Jews and attribute crimes to them committed against this background, see Buchen, “'Herkules'," 210.

44 "Proces Rittera," Gazeta Lwowska 74 (1884), 226:4.

45 "Kronika sądowa," Gazeta Lwowska 72 (1882), 286:4.

${ }^{46}$ On the transfer of land to Jewish ownership and the resentments and rivalry this caused, see Kai Struve, Bauern und Nation in Galizien: Über Zugehörigkeit und soziale Emanzipation im 19. Jahrhundert (Göttingen, 2005), 416.

47 “Sprawy sądowe. Mord w Lutczy,” Czas 37 (1884), 226:3. 


\section{The affair}

Let us recall what the "Ritter affair" was all about. In March 1882, two boys found a decomposing body in a hardly accessible gully. District judge Radwański, medical examiner Tadeusz Bieliński and a second medical examiner from Frysztak, Emanuel Meydel (Majdel/ Maidel), were informed. Based on the clothing, it was ascertained that the body was that of the poor 35-year-old charwoman Franciszka (Frania/Franka) Mnichówna. Her chopped-off plaits were found close by. She had been murdered in late 1881. According to the doctors:

the deceased did not die in the place where she was found; received a blow to the left side of the head with a heavy and blunt object, which broke her jaw, her throat was cut, her stomach sliced open and the uterus and foetus with the placenta were removed; her hair was also cut off her head and her sexual organs removed; the direct cause of death is therefore cutting of the throat, from which she must have died within a few minutes. ${ }^{48}$

Last time the victim had been seen, was at the home of Marceli Stochliński's wife in November or December 1881, whence she was to go to visit the Ritters. ${ }^{49}$ Mnichówna had the extremely close relationships with the Jews. She called Mr. Ritter "father" and Mrs. Ritter "mother." According to the rumors, the priest had denied her absolution because "she got involved with Jews and communed with married men." ${ }^{50}$ Mnichówna had thereby crossed the unwritten line between two worlds-the Jewish and the Christian one. Worse still, unlike Stochliński she did not see anything objectionable in her conduct. Not only did she work as a servant for Jews, but she did so willingly, placing the Ritters above other, Christian employers. ${ }^{51}$

48 "Sprawy sądowe. Skrytobójcze morderstwo w Lutczy,” NR 3 (1884), 226:3; “Z izby sądowej (Zbrodnia lutczańska, oryginalne sprawozdanie Gazety Lwowskiej), Rzeszów, 11 grudnia," Gazeta Lwowska 72 (1882), 283:3-4; "Proces Ritterów," Gazeta Lwowska 74 (1884), 226:4.

49 "Kronika sądowa (Zbrodnia lutczańska), Rzeszów, 18 grudnia," Gazeta Lwowska 72 (1882), 289:4; "Sprawy sądowe. Morderstwo skrytobójcze, Rzeszów, 18 grudnia," Czas 35 (1882), 290:3.

${ }_{50}$ "Z izby sądowej," Gazeta Narodowa 21 (1882), 283:2; "Z izby sądowej,” Dziennik Polski 15 (1882), 285:2; also "Proces Ritterów," Gazeta Lwowska 74 (1884), 226:4; "Sprawy sądowe. Morderstwo skrytobójcze, Rzeszów, 12 grudnia," Czas 35 (1882), 285:2-3.

${ }^{51}$ On the circular of Archbishop Wierzchlejski of Lwów from 1867, which presented service of Jews as a deadly sin, see Majer Bałaban, Dzieje Żydów w Galicyi i w Rzeczypospolitej krakowskiej 1772-1868 (Lwów, [n.d.]; reprint 1988), 183. On the tradition of prohibitions 
After the body was found, the police combed the village, interrogating residents. The path to the gully where the corpse was found led from the Ritters' cellar past Stochliński's window, which placed the suspicion heavily on both parties. ${ }^{52}$ Rumors in the village had it that "Frania could only have died among the Jews," thus increasing the police's interest in the Ritter family. ${ }^{53}$ Following the investigation, and admonished by Father Drzewicki, ${ }^{54}$ Marceli Stochliński confessed to the crime, implicating the Ritters and their daughters in his testimony. ${ }^{55}$ Stochliński testified that the Ritters had paid him to help with murdering Franka in their cellar. He had held the woman while Moses cut her throat with the help of his wife and two daughters. ${ }^{56}$ The testimony contained motives of Jewish witchcraft: supposedly Ritter had once cast a spell that caused his neighbor to go blind. ${ }^{57}$ Witnesses were found who accused Ritter of having threatened them with blindness and poverty.$^{58}$ The testifying peasants repeated rumors that the Jews had taken the girl for making matzo (sic: Franka was 35 years old!) and that she had died among Jews. ${ }^{59}$ Similar facts (i.e. murders) had supposedly taken place in Krosno and Błażowa with Christian women getting involved with male Jews. ${ }^{60}$ The source of this gossip, ironically enough, was Gitla Ritter herself: "for her, news that Franka had died among Jews always fell on deaf ears, as she knew the false folk superstition that Jews need Catholic blood for their matzo" and had laughed at the rumors. ${ }^{61}$

In prison, Stochliński revoked his testimony, claiming that he had made it under pressure from police officers. To fellow prisoners, however, he confessed to committing the crime of which he and the Ritter family

on Jews having Christian servants, see Philip Friedmann, Die galizischen Juden im Kampfe um ihre Gleichberechtigung (1848-1868) (Frankfurt am Main, 1929), 101f.

52 "Proces Ritterów," Gazeta Lwowska 74 (1884), 229:4.

53 "Sprawy sądowe. Skrytobójcze morderstwo w Lutczy," NR 3 (1884), 230:4; "Proces Ritterów," Gazeta Lwowska 74 (1884), 226:4.

54 "Sprawy sądowe," NR 1 (1882), 18:2.

55 “Z izby sądowej,” Dziennik Polski 15 (1882), 287:3.

56 "Kronika sądowa (Zbrodnia lutczańska), Rzeszów, 14 grudnia," Gazeta Lwowska 72 (1882), 286:3.

57 "Sprawy sądowe. Morderstwo w Lutczy," NR 1 (1882), 12:2.

58 "Sprawy sądowe. Morderstwo w Lutczy," NR 1 (1882), 16:4.

59 “Sprawy sądowe. Morderstwo w Lutczy," NR 1 (1882), 14:3.

60 "Sprawy sądowe. Morderstwo w Lutczy," NR 1 (1882), 14:3; "Sprawy sądowe. Morderstwo w Lutczy. Kraków, 4 października," Czas 37 (1884), 232:5; “Z izby sądowej,” Dziennik Polski 15 (1882), 286:2.

${ }^{61}$ "Kronika sądowa (Zbrodnia lutczańska), Rzeszów, 12 grudnia," Gazeta Lwowska 72 (1882), 285:3. 
were accused. ${ }^{62}$ Attempting to escape the blame himself, he increasingly emphasized the Ritters' role in the murder.

\section{The first trial in Rzeszów, 10-21 December 1882}

The first trial took place in Rzeszów between 10 and 21 December 1882. ${ }^{63}$ Stochliński's defense counsel, Dr. Koppel, appreciated the role of the trial for the city's development:

Our quiet and conservative city, since the lustre of the famous Rzeszów gold wore off, has been forgotten in the history of Galicia; doubts began to be raised about its future, yet unjustly. Providence has assigned a place in history to Rzeszów, and among other evidence of this concern for our town, without doubt the trial that is now coming to an end occupies a substantial place. ${ }^{64}$

We might therefore view Dr. Koppel's faith in the trial's impact on Rzeszów's image as something of a forerunner for contemporary "dark tourism," as he expressed his hope that it would increase the city's attractiveness in the media. (Probably his hope was inspired by the first Tiszaeszlár trail in the small, provincial and unattractive town Nyireghyháza that was followed by "the whole world." ${ }^{\prime 5}$ ) The press hubbub that accompanied the affair was most desirable, according to the defense counsel in the trial. Probably it was why expert testimony was sought in Vienna, rather

62 "Sprawy sądowe. Skrytobójcze morderstwo w Lutczy," NR 3 (1884), 227:2-3.

63 "Sprawy sądowe. Morderstwo skrytobójcze, Rzeszów, 11 grudnia," Czas 35 (1882), 283:2; also Czas 35 (1882), 284:3; "Z izby sądowej (Morderstwo z pobudek religijnych)," Gazeta Narodowa 21 (1882), 283:2; "Z izby sądowej. Rzeszów, 11 grudnia (Skrytobójstwo w Lutczy),” Dziennik Polski 15 (1882), 283:2.

Head of the Tribunal [Stanisław] Mossor, assessors Schmied/Szmid and Hanasiewicz, deputy adjunct Kawski, court reporter Sławiński.

Defense: counsels Dr. [Józef] Fechtdegen and Dr. Koppel, notary [Jan] Pogonowski, deputy prosecutor Dr. Pogorzelski. As jurors only peasants and petty bourgeoisie, one citizen (Rylski).

Medical examiners: Dr. Barzycki from Rzeszów and Dr. Bieliński from Strzyżów.

Józef Fechtdegen, born in 1841. Worked as a counsel (adwokat) in Rzeszów from 1873. Also, a member of the Kraków Legal Advisers Chamber. For over thirty years a member of Rzeszów City Council. In addition, the first and then second deputy mayor of Rzeszów. His actions contributed to the growing importance and status of Jewish representatives among the Rzeszów authorities. Died in Kraków on 26 January 1905. Buried at the Rzeszów Israelite cemetery. Tomasz J. Kotliński, "Józef Fechtdegen," in [A]dwokaci galicyjscy, http:// kancelariajaroslaw.pl/adwokaci_galicyjscy.html [retrieved: 14 Jan. 2018].

64 "Sprawy sądowe. Morderstwo skrytobójcze," Czas 35 (1882), 292:3; "Z izby sądowej," Dziennik Polski 15 (1882), 292:2.

${ }^{65}$ Hartston, Sensationalizing the Jewish Question, 142. 
than from Rabbi Simon Schreiber in Cracow who was a widely recognized rabbinical expert and a politician (a member of the Polish Circle in the Parliament in Vienna). This is how the trail got a supraregional importance and drew attention first of Viennese and later of international press. Paradoxically, according to Koppel, it was providence that was to thank for the murder and its international resonance.

Entrance to the courtroom was by ticket only, but despite this it was overcrowded. The trial was reported on by correspondents from Dziennik Polski, Gazeta Narodowa, Gazeta Lwowska and Nowa Reforma. ${ }^{66}$ The course of the trial was symbolically set by Teofil Merunowicz, who during speeches in the Regional Assembly (Sejm Krajowy) cited the murder in Lutcza as an example of the existence of a secret Jewish law, resulting in protests from deputies Dr. Filip Fruchtman, Bernard Goldmann and Filip Zucker ${ }^{67}$ At the beginning of the trial, Merunowicz's refutation appeared in Nowa Reforma:

I must officially protest against the statement that I maintained in the Assembly that the atrocity in Lutcza was committed for ritual purposes, i.e. as a rite, as may or may not have occurred in Tiszaeszlár. I said that Franciszka Mnichówna was murdered in Lutcza "for religious motives to satisfy the superstitious rules of the Talmud." This referred to the removal of the foetus that was in her-and not to her blood being needed for any ritual purposes. ${ }^{68}$

In total, 44 witnesses and two doctors were questioned. The villagers' testimonies were sometimes difficult to understand, since they used local dialect and idiosyncratic terms. ${ }^{69}$ Dr. Bieliński and the surgeon Emanuel Meydel had removed the part of the corpse (the uterus) from which the foetus was taken and sent it to the Jagiellonian University for analysis. ${ }^{70}$ Bieliński's statement was somewhat contradictory to the information he gave immediately after the autopsy, and the experts in Cracow (Browicz and Żóławski) gave a different verdict to their two colleagues regarding

66 “Z izby sądowej,” Dziennik Polski 15 (1882), 284:2. Notably, this liberal newspaper did not mention the correspondents for Czas, but only those of Dziennik Polski, Gazeta Narodowa, Gazeta Lwowska and Nowa Reforma.

${ }^{67}$ Sprawozdanie. 6. posiedzenie 5. sesyi IV. peryodu Sejmu galicyjskiego z dnia 14 września 1882, p. 70; Sprawozdanie. 22. posiedzenie 5. sesyi IV. peryodu Sejmu galicyjskiego z dnia 10 października 1882, p. 422.

68 "Korespondencja Nowej Reformy," NR 1 (1882), 10:2. Merunowicz cited press articles as evidence, which demonstrates how important an organ the press had become.

69 "Sprawy sądowe. Morderstwo skrytobójcze, Rzeszów, 12 grudnia," Czas 35 (1882), 285:2-3.

70 "Sprawy sądowe. Morderstwo w Lutczy," NR 1 (1882), 18:3. 
the significance of the blows to the head. ${ }^{71}$ The defense therefore asked that both documents be read out, but the court denied their request. When this denial was announced, on the basis of the numerous doubts over the actual cause of death and the significance of the injuries, Dr. Fechtdegen on behalf of the defense moved for an adjournment of proceedings and exhumation of the remains in order to supplement the autopsy report and send the results to the Cracow department for review. Gazeta Lwowska reported that this motion was also denied:

Prosecutor Pogorzelski noted that the motives for the crime were the laws of the Talmud, the desire to remove material losses and avoid a series of troubles within the family that might arise as a result of Mnichówna's condition. Evidence is provided by the testimony of Stochliński, who has not the slightest idea about the Talmud, and yet following the deed related facts which are closely related to the laws of the Talmud. The murder was carried out by Ritter, the presence of women [was caused by] a Talmudic requirement. ${ }^{72}$

In his summing-up, Ritter's defense counsel Jan Pogonowski emphasized the circumstantial nature of the investigation and the police's forceful "persuasion" of Stochliński to confess and to name his accomplices. ${ }^{73}$ Pogonowski conjectured that the perpetrator might have been Stochliński himself, to whom the police offered a line of defense, i.e. blaming the Ritters. Apart from these accusations, the defense claimed, there was no evidence against the Ritters. Dr. Fechtdegen, defending Gitla and the couple's daughters, Bajla and Chaja, argued that the motives for murder were private interest, rather than religious-based. ${ }^{74}$ Since there was no evidence against the accused, however, supposed reasons for the crime had been sought in the Talmud. Murder had been used to arouse religious fanaticism, and the trial given unwarranted notoriety in Europe. Ritter could have just paid Franka off. The letter of the Vienna rabbinate clearly referred to a prohibition on mutilating dead bodies. Cutting of hair was not practised on corpses. "And the prosecution's insinuation that Ritter might have regarded Mnichówna as a Jewess is simply at odds with all

71 “Sprawy sądowe. Morderstwo w Lutczy,” NR 1 (1882), 19:3.

72 "Kronika sądowa (Zbrodnia lutczańska), Rzeszów, 20 grudnia," Gazeta Lwowska 72 (1882), 291:3-4.

73 "Sprawy sądowe. Morderstwo w Lutczy," NR 1 (1882), 21:4; "Sprawy sądowe," Gazeta Lwowska 72 (1882), 291:4; "Sprawy sądowe. Morderstwo skrytobójcze, Rzeszów, 20 grudnia," Czas 35 (1882), 293:2-3.

74 "Sprawy sądowe. Morderstwo w Lutczy," NR 1 (1882), 21:4. 
Jewish laws." ${ }^{\text {" F }}$ Fechtdegen claimed that it was only the request for the assessment of the Vienna rabbinate that had given the affair unwarranted notoriety, exploited by troublemakers and enemies of Jews. ${ }^{76}$

The tribunal failed to call a number of witnesses proposed by the defense. ${ }^{77}$ The jury in Rzeszów believed the testimony of the drunkard Stochliński, and interpreted the evidence as confirmation of the suspicion of ritual murder. ${ }^{78}$ The court ignored the testimonies of the spice trader and synagogue warden (Schulvater) Aron Kanner and barber Jakób Schütz $^{79}$ from Strzyżów, as well as the official statement of the Vienna rabbinate. These explained that according to the Talmud, the foetus of a dead woman should be cut out and the hair of the deceased unplaited, ${ }^{80}$ but that this only applied to Jewish women. ${ }^{81}$ The child of a Christian woman was regarded as a Christian (authority of Salomon Spira from Hungary), as attested by Jakób Fleissig, assessor of the Vienna rabbinate. In spite of all these inconsistencies, jurors found Moses and Gitla Ritter and Marceli Stochliński guilty. For some reason, however, despite Stochliński's evidence, they exonerated the daughters, Bejla and Chaja. ${ }^{82}$

They were sentenced to death by hanging, and if this sentence is approved by His Honor, the execution is to take place in the following order: first Gitla Ritter shall be hanged, then Stochliński, and finally Moses Ritter. ${ }^{83}$

Neither the jury in Rzeszów nor the reporter for the Tarnów newspaper Unia had any doubt as to Moses Ritter's guilt. The latter characterized him as an immoral, debauched and lecherous man, and was certain that

75 Ibid. 293:3.

76 "Sprawy sądowe. Morderstwo skrytobójcze, Rzeszów, 20 grudnia," Czas 35 (1882),

77 "Sprawy sądowe. Morderstwo skrytobójcze, Rzeszów, 14 grudnia 1882,” Czas 35 (1882), 288:3.

${ }_{78}$ On the Galician jury courts, which were criticized for unjust verdicts and the low intellectual level of jurors, see Kotliński, Kotliński, Sądownictwo powszechne w Galicji, 210. "Sprawy sądowe. Morderstwo w Lutczy," NR 1 (1882), 13:4; "Sprawy sądowe. Morderstwo w Lutczy," NR 1 (1882), 15:3.

79 "Sprawy sądowe. Morderstwo w Lutczy," NR 1 (1882), 14:3.

80 "Telegramy Nowej Reformy (prywatne). Morderstwo w Lutczy, 12 grudnia," NR 1 (1882), 11:3.

81 "Sprawy sądowe. Morderstwo w Lutczy,” NR 1 (1882), 14:3.

82 "Sprawy sądowe," NR 1 (1882), 20:3; "Doniesienie Gazety Narodowej dotyczące procesu Ritterów toczącego się w Rzeszowie, Lwów 1882,” in Żbikowski, Dzieje Żydów w Polsce, 29-30.

83 “Kronika sądowa (Zbrodnia lutczeńska), Rzeszów, 21 grudnia," Gazeta Lwowska 72 (1882), 292:4. 
"for certain Talmudic requirements, the innards were cut out, after which the body was carried away in the night and left near to the stream." ${ }^{\prime 4}$ The same author also commented that:

For a long time it was not known what had happened to Franciszka Mnichówna, but the voice of the people, about which it was said vox populi, vox Dei, identified the culprit; and the fact that this public voice was not mistaken has been proven by a thorough investigation. ${ }^{85}$

Very similar comments came in the Cracow-based $\mathrm{Czas}^{86}$ (also including the argument of vox populi, which was always right; interestingly, Czas made this argument even before the trial!). The Nowa Reforma reporter also seemed convinced of Ritter's guilt and the ritual nature of the murder. Yet this publication's editors protested in a leading article against prejudging the accused's guilt before the court reached its verdict, and "involving religious issues in the matter [of the murder]," as well as distancing themselves from Merunowicz, whose rhetoric was described as being "laden with crude antisemitism." ${ }^{\prime 7}$ Nowa Reforma also cited King Stephen Báthory's rescript from 1576, which referred to the groundlessness of blood libel. Following the trial, meanwhile, the December issue of Nowa Reforma featured the article "Prejudices and Superstitions," which states that the duties of thinking individuals include:

above all removing books that keep the people superstitious or incite them to superstitious actions, especially works of market literature, theosophical, cabbalistic, or Egyptian dream books. ${ }^{88}$

This suggests that such superstitions and prejudices were thought to enjoy great popularity in the countryside and among the lower classes, irrespective of religious denomination. Jews as other countryside inhabitants were also seen as more backward and superstitious than urban Jews. Alleged practice of ritual murder among Jews could therefore be regarded as a natural consequence of the superstitions in force.

84 “Morderstwo skrytobójcze," Unia 1 (1882), 15:4.

${ }^{85}$ Ibid. „Vox populi” was quoted also during trails in Imperial Germany. See Hartston, Sensationalizing the Jewish Question, 121.

86 "Sprawy sądowe. Morderstwo skrytobójcze, Rzeszów, 11 grudnia," Czas 35 (1882), 285:2. Ritter's trial is mentioned by Paweł Popiel, Pamiętniki (1807-1892) (Kraków, 1927), 200.

87 "Kraków, 5 października," Reforma 2 (1882), 226:1; “Kleine Chronik, Krakau,” Neuzeit 22 (1882), 41:350.

88 “Przesądy i zabobony," NR 1 (1882), 24:3. 


\section{Revocation, 7 May 1883}

The revocation hearing took place on 7 May 1883 in Vienna, presided over by court attorney Wierzbicki, while the convicted parties were represented by counsels Dr. Adolf Stein from Vienna and Dr. Fechtdegen from Rzeszów. The main point of the invalidity grievance was the fact that the Rzeszów court had not obtained a superassessment from the medical faculty, although the excessive conclusions of the expert Dr. Biliński [sic!] appeared to lack a sufficient basis in the autopsy. This point of invalidity was also acknowledged by general prosecutor Simonowicz, and the Supreme Tribunal revoked the jury verdict and sentence of the Rzeszów court and ordered a repeat trial and sentence to be carried out by the Cracow jury tribunal in its next term. ${ }^{89}$

The grounds for revocation were therefore the lack of official assessment from the medical faculty; "in all other points, the Revocation Tribunal rejected the motion." "90 According to Neue Freie Presse, after the Rzeszów sentences were revoked, August Rohling wrote to the Lviv Supreme Court with the assurance that the ritual murder was a fact. ${ }^{91}$

All efforts were made during the preparation of the Cracow trial to correct the errors of the one held in Rzeszów ("we in Cracow are more enlighten and competent than they in little Rzeszów"). ${ }^{92}$ Many Lutcza residents were called upon to testify again. A further complication is the fact that the first pathologist involved in the case, Strzyżów surgeon Meydel/Majdel/Maidel, had since died, and the anatomical specimen used to state that the foetus had been cut out had been thrown away. ${ }^{93}$

89 "Sprawy sądowe," NR 2 (1883), 104:3; on the Administrative Tribunal revocations see Andrzej Dziadzio, Monarchia konstytucyjna w Austrii 1867-1914. Władza - obywatel prawo (Kraków, 2001), 203-205. Jakób Simonowicz/Szymonowicz was a member of the "Poles from Galicia" group; see ibid., 33 and 64, n. 13. He retired in 1891, as president of the Superior Regional Court in Lwów; see "Kronika," NR 10 (1891), 195:3.

90 "Sprawy sądowe (Skrytobójcze morderstwo w Lutczy)," NR 3 (1884), 226:3; "Proces Ritterów," Gazeta Lwowska 74 (1884), 235:4. Incompetence of local doctors was also an argument in the Tiszaeszlár trail; Hartston, Sensationalizing the Jewish Question, $143 \mathrm{f}$.

91 "Noch gibt es Richter in Österreich," Neuzeit 24 (1886), 11:1-2. The article quoted Neue Freie Presse.

${ }_{92}$ "Kronika," NR 3 (1884), 184:2; a figure of 66 sheets was also given, see: "Sprawy sądowe. Morderstwo w Lutczy," Czas 37 (1884), 26:4-5.

93 "Sprawy sądowe," NR 3 (1884), 223:3. 


\section{The second trial in Cracow, 1-11 October 1884}

We know the names of all the participants in the trial. ${ }^{94}$ The court was presided over by Lubaszek, the counsel for the prosecution was deputy prosecutor Łoziński, and the defense counsels Dr. Maksymilian Machalski, Dr. Józef Rosenblatt and Dr. Lechosław Boroński ${ }^{95}$ (all three were city councillors). As had been the case in Rzeszów, tickets were required for entry to the courtroom:

For several days, head of the penal court, Mr. Czyszczan, had been inundated with requests for tickets, and it is thanks to his energetic work that the trial did not take on the character of a spectacle held for the audience, as has sometimes been the case in sensational foreign trials ... We were pleased to note that only few women attended, and those who did soon left the room..$^{96}$

It was emphasized with some satisfaction that the "[r]oom was overflowing with intelligent members of the public, with very many court officials and state prosecutors among them." court building, especially Orthodox Jews. The presence of "a throng of correspondents and illustrators" from the Vienna press was noted, ${ }^{98}$ as a result of the European notoriety that the Ritter case had acquired, like the Tiszaeszlár case before it. Commentators delighted in describing the appearance of the courtroom and its macabre attributes. "Maps of the village are hung on the wall, and on a separate table lie the corpora delicti, among which are the murder weapons and the victim's skull." ${ }^{99}$

94 "Sprawy sądowe. Skrytobójcze morderstwo w Lutczy," NR 3 (1884), 226:3. All three defense counsels were city councillors, Boroński was the co-editor of Nowa Reforma.

${ }^{95}$ In this trail there were ultimately no Jewish jurors, although they were generally also selected; see: "Sprawy sądowe," Czas 37 (1884), 230:3. Jerzy Zdrada, "Machalski Maksymilian," in Polski Stownik Biograficzny (Wrocław, 1973), 18: http://www.ipsb.nina.gov.pl/a/ biografia/maksymilian-machalski?print [retrieved: 21 Jan. 2018].

Jan Widacki, "Adwokat profesor Józef Rosenblatt i jego udział w krakowskim procesie Ludwika Waryńskiego i towarzyszy," Palestra 11-12 (2013), 124-127, http://palestra.pl/old/ pdf_pliki/17_widacki_adwokat.pdf [retrieved: 21 Jan. 2018].

96 “Sprawy sądowe. Morderstwo w Lutczy, Kraków, 30 września,” Czas 37 (1884), $227: 3$.

97 "Sprawy sądowe. Skrytobójcze morderstwo w Lutczy," NR 3 (1884), 227:2-3.

98 “Z izby sądowej (proces Rittera)," Gazeta Narodowa 23 (1884), 227:3; "Sprawy sądowe," NR 3 (1884), 223:3. Unfortunately, I was unable to find any illustrations of the second or third trial.

99 “Proces Rittera," Gazeta Lwowska 74 (1884), 226:4. 
The Nowa Reforma reporter was evidently still convinced of the Ritters' guilt, and from the very beginning of the trial referred to Moses as "the chief perpetrator of the murder." 100

There were no Jews among the jurors, which is interesting since Jewish citizens generally occupied such roles. ${ }^{101}$ Nowa Reforma emphasized that the verdicts of professionals-doctors and engineers—had been obtained. The court admitted additional witnesses. Some of them gave vague testimonies, and those testifying for a second time changed the tenor of their statements. The peasant witnesses cited various rumors circulating in Lutcza and several suspicious things that the Ritter family had said. ${ }^{102}$ It also turned out that the villagers used a different calendar than residents of the town (although they were all Catholics), ${ }^{103}$ and so the date of Mnichówna's death was moved two weeks back.

In his testimony, Stochliński again cited the rumors that the Jews had murdered Franka, claiming that he was entirely innocent. ${ }^{104}$ Moses Ritter, meanwhile, vowed that he had not murdered Mnichówna, and that he was incapable of committing such a crime. ${ }^{105}$ Ritter believed that Stochliński was accusing him because he had been convinced to do so by somebody else, and that the cause of this anger harbored toward him were misunderstandings over land. On this occasion, the motiv of religious fanaticism was left out of the charges (as all reports noted) ${ }^{106}$ but it was clearly hinted at by Łoziński, the deputy prosecutor, whose address referred to the crime as a reminder of the dark days. ${ }^{107}$ According to the prosecution, the atrocity in Lutcza differed from ordinary murders in its exceptional cruelty and planned nature. Commentators drew attention to the testimony of Lutcza's parish priest, Father Jakub Drzewicki, who "used the Rohling argument": he had once read in Mr. Rohling's Polish translation of the Talmud that Jews who have seduced a Christian woman are obliged to cut her stomach

100 “Sprawy sądowe. Skrytobójcze morderstwo w Lutczy, Kraków, 1 października,” NR 3 (1884), 228:2.

101 E.g., "Wylosowani sędziowie," NR 3 (1884), 229:3.

102 "Proces Rittera," Gazeta Lwowska 74 (1884), 231:5.

103 "Sprawy sądowe. Skrytobójcze morderstwo w Lutczy," NR 4 (1885), 213:2.

104 "Sprawy sądowe. Skrytobójcze morderstwo w Lutczy,” NR 3 (1884), 227:2.

105 "Proces Rittera," Gazeta Lwowska 23 (1884), 228:4.

106 "Sprawy sądowe. Skrytobójcze morderstwo w Lutczy, Kraków, 1 października," NR 3 (1884), 228:2.

107 “Proces Ritterów," Gazeta Lwowska 23 (1884), 235:4. 
open and remove the foetus from her womb. ${ }^{108}$ This is also mentioned by Jakub Drzewicki's brother, Jan, also a priest.

This time too, the court did not attach importance to testimonies that could exonerate the Ritters. ${ }^{109}$ Moses Ritter's defense counsel, Dr. Machalski, pointed to his client's lack of motive and the shakiness of the medical faculty's statement (as a result of a lack of evidence):

[Machalski] having said several words about the suspicion, mentioned in passing, that religious motives played a certain role, expresses ... the conviction that this suspicion, strongly rooted in the mind of the Lutcza parish priest, was a major factor in instilling the belief in the entire population that Franka died at the hands of Jews. ${ }^{110}$

Gitla Ritter's defense counsel, Dr. Rosenblatt, on the other hand, concentrated on the media storm surrounding the trial and highlighted the unwarranted notoriety of the case and the prejudices that had preceded it. ${ }^{111}$

Yet Rosenblatt's hopes of an independent and just verdict were dashed: all three got death sentence again. ${ }^{112}$ Stochliński accepted the death penalty, while the Ritters filed their opposition through their defense counsels. ${ }^{113}$ According to public opinion, as represented by Nowa Reforma, the trial was held in exemplary and unbiased fashion, the proof of which was supposedly the thanks to court councillor Lubaszek submitted after the trial by the jurors. The defense disagreed, stating of the jury that "only a vivid imagination could have led to a guilty verdict." 114 A pamphlet circulating in Cracow following the trial recommended, in the light of the verdict, not losing sight of religious fanaticism, and using all available means to help to prevent abuses and "ritual crimes" in future. ${ }^{115}$ In Vienna, Österreichische Wochenschrift published a summary of a lecture by Prof. Eduard Hofmann

108 Żyndul, Kłamstwo krwi, 155. A translation of Rohling's treatise was published in Lwów in 1874; see Żbikowski, Żydzi krakowscy i ich gmina, 275.

109 “Sprawy sądowe. Skrytobójcze morderstwo w Lutczy,” NR 3 (1884), 229:2 and 230:4.

110 Żyndul, Kłamstwo krwi, 155; quoted in Izraelita (1885), 40.

111 "Proces Ritterów," Gazeta Lwowska 74 (1884), 235:4; "Sprawy sądowe. Morderstwo w Lutczy, Kraków, 9 października,” Czas 37 (1884), 235:3; “Z izby sądowej, Kraków, 10 października (Morderstwo w Lutczy dokończenie)," Dziennik Polski 17 (1884), 236:2.

112 "Sprawa Ritterów," Przegląd Rzeszowski 3 (1885), 19:6; "Sprawy sądowe," NR 3 (1884), 236:4; Żyndul, Kłamstwo krwi, 155.

113 "Sprawy sądowe. Skrytobójcze morderstwo w Lutczy," NR 3 (1884), 230:4 and 236:4.

114 “Sprawy sądowe. Skrytobójcze morderstwo w Lutczy (Trzeci dzień rozprawy),” NR 4 (1885), 216:2.

115 “Z powodu procesu Ritterów,” NR 3 (1884), 245:3. 
given to a large audience in Vienna, containing a damning indictment of the way in which the autopsy on Mnichówna's remains was performed, as well as the Cracow lawyers' use of the evidence. ${ }^{116}$

\section{Revocation, 25 February 1885}

On 25 February 1885, the sentence of the court was again quashed by the Supreme Tribunal. Neue Freie Presse reported that the Cracow prosecutor protested the defense's application to read out the justification for the revocation verdict from Vienna. ${ }^{117}$ This justification mentioned the fact that the Cracow doctors' autopsy displayed several inaccuracies and contradicted the results of the autopsy conducted before the Rzeszów trial. ${ }^{118}$ In Vienna, the explanations of the Cracow court that the injuries to the body made it difficult to identify the murdered party were also rejected, since the deceased's clothing made identification easy. Stochliński's testimony was regarded as shaky and unreliable. The Supreme Tribunal referred the case to the Cracow Regional Court for reassessment. ${ }^{119}$ The files were resubmitted to the state prosecutor's office. ${ }^{120}$ Łoziński, the deputy prosecutor known from the previous trial, who was using an antisemitic rhetoric, was to prepare the new charges.

\section{The third trial, 17-29 September 1885}

The third trial of the Ritters no longer aroused such supraregional interest as the previous two: Gazeta Lwowska confined itself to informing of the new death sentence and the defense's invalidity motion. ${ }^{121}$ Dziennik Polski provided, as it had during the second trial, a heavily condensed account

116 "Vermischte Nachrichten," Österreichische Wochenschrift 1 (1884), 2:6-7. Probably identical with Dr. Eduard Hofmann who was the medical expert in the Tiszaeszlár trail; see Hartston, Sensationalizing the Jewish Question, 144.

117 "Noch gibt es Richter in Österreich," Neuzeit 26 (1886), 11:2. The article quoted Neue Freie Presse.

118 “Sprawy sądowe,” NR 5 (1886), 226:3; "Sprawy sądowe. Sprawa Ritterów,” Czas 38 (1885), 213:3.

119 "Sprawa Ritterów," Kuryer Rzeszowski 4 (1886), 6:7; “Sprawa Ritterów przed Najwyższym Trybunałem," Przeglad Rzeszowski 3 (1885), 7:7.

120 "Sprawa Ritterów," Przeglad Rzeszowski 3 (1885), 11:7.

121 “W procesie Ritterów,” Gazeta Lwowska 75 (1885), 222:4. 
of the trial. ${ }^{122}$ Nowa Reforma, no doubt because of the place of the action and engagement of the local elite, was still excited by the story:

Before a tribunal of jurors, today a trial began which continues to cause immense interest in the widest circles. The crime committed four years ago against Franciszka Mnichówna has acquired a remarkable notoriety not only because of the mysterious motives suspected of the murderer, but also the unexpected turn that the case took as a result of the two rulings of the Supreme Tribunal, which in each case annulled the sentence handed out on the basis of a unanimous jury verdict. ${ }^{123}$

As before, entry to the courtroom was by ticket and a courtroom and gallery overcrowded. ${ }^{124}$

Influenced by information in the foreign press, a new topic appeared in Cracow press reports: the suspicion of deficiencies in the first autopsy, which might have influenced the appearance of the subject of rituals:

The ritual motive was abandoned by the prosecution in the amended charges, and psychologically it would be difficult to justify this murderous act; it may be that the main cuts observed in the stomach region were only made incidentally by the pathologists. ${ }^{125}$

The doctors, however, including the first pathologist, Dr. Bieliński, maintained that the foetus had been cut out. ${ }^{126}$ The shakiness and lack of credibility of Stochliński's testimony was again emphasized. The statement of police Wachtmeister Stanisław Kościeński testifying that public opinion regarded Jews as the perpetrators of the crime was cited. ${ }^{127}$ It is unclear what the defense counsel Machalski was referring to by the "thieves' candle" superstition. ${ }^{128}$ Did he believe that an accusation based on superstition can be weakened by citing another superstition? In any case, he mentioned a superstition:

122 “Z izby sądowej, Kraków, 18 września (Sprawa Ritterów)," Dziennik Polski 18 (1885), 216:3 and 223:2-3.

123 "Sprawy sądowe. Skrytobójcze morderstwo w Lutczy,” NR 4 (1885), 212:2.

124 "Rozprawa przeciw Ritterom,” Przegląd Rzeszowski 3 (1885), 18:6; "Rozprawa przeciwko Ritterom," Kuryer Rzeszowski 4 (1886), 16:7; "Sprawy sądowe. Skrytobójcze morderstwo w Lutczy," NR 38 (1885), 212:2.

125 “Sprawy sądowe. Sprawa Ritterów,” Czas 38 (1885), 213:3.

126 "Sprawy sądowe. Skrytobójcze morderstwo w Lutczy," NR 4 (1885), 219:2; "Sprawy sądowe. Sprawa Ritterów," Czas 38 (1885), 221:3; "Sprawa Ritterów,” Kuryer Rzeszowski 4 (1886), 10:7.

127 "Sprawy sądowe. Sprawa Ritterów,” Czas 38 (1885), 217:3.

128 "Sprawy sądowe. Sprawa Ritterów,” Czas 38 (1885), 221:3. 
which was apparently rife in the local population and which led the defense to believe that the crime might have been committed for other motives and by another perpetrator. Dr. Bieliński testified that in certain villages there was a widespread belief that a thief, in an effort to be invisible, should form a candle out of a foetus removed from a murdered woman. ${ }^{129}$

In his defense speech, Machalski pointed to the lack of motive and the circumstantial nature of the case. Boroński, meanwhile, questioned the veracity of Stochliński's testimony owing to its shaky character and police coercion. The defense noted that Moses Ritter was absent from Lutcza on the day of the murder. ${ }^{130}$ According to Machalski, the motive of alleged ritual murder had been consolidated under the influence of the Lutcza parish priest, who ensconced the idea among the population. ${ }^{131}$ The defense argued that nothing fit: neither the motive, nor the time, nor the place. The participation of the wife and daughters also made no sense. Furthermore, there was no proof that the remains had been moved to the gully.

Rosenblatt, representing Gitla, again spoke about the notoriety that the case had "wrongly" acquired. ${ }^{132}$ The only evidence against Gitla was Stochliński's testimony. Moses Ritter himself presented Stochliński as the only source of all the slander, ${ }^{133}$ ascribing much of his statement to "a rebellion raised against him." 134

All in all, the witnesses' statements did not add anything new. What did appear were reasonable doubts as to whether Franka Mnichówna was murdered at all: a reason for her injuries could have been also an accidental fall in a gully and later activities of wild animals that attacked her post mortem. Czas did not quote the prosecutor's speech, which can be attributed to self-censorship to remove an argument that could portray the way in which the trial was conducted in Cracow in a negative light. ${ }^{135}$ According to the Österreichische Wochenschrift reporter, the prosecutor

129 "Sprawy sądowe. Skrytobójcze morderstwo w Lutczy, Kraków, 29 września 1885," NR 4 (1885), 222:2.

130 “Sprawy sądowe. Skrytobójcze morderstwo w Lutczy,” NR 4 (1885), 213:2.

131 "Parish priest Drzewicki mentions the laws from the Talmud, which he read in a Polish translation from last century while studying in Lwów." "Sprawy sądowe. Skrytobójcze morderstwo w Lutczy, Kraków, 23 września," NR 4 (1885), 214:2; "Sprawy sądowe. Skrytobójcze morderstwo w Lutczy," NR 4 (1885), 219:2.

132 "Sprawy sądowe. Sprawa Ritterów," Czas 38 (1885), 222:2.

133 "Sprawy sądowe. Skrytobójcze morderstwo w Lutczy," NR 4 (1885), 216:2.

134 “Sprawy sądowe. Sprawa Rittera, Kraków, 18 września,” Czas 38 (1885), 214:3.

135 “Sprawy sądowe. Sprawa Ritterów, Kraków, 28 września,” Czas 38 (1885), 222:2. 
continued to demand punishment for a murder committed for religious reasons. ${ }^{136}$ Loziński apparently asked rhetorically:

Are country folk capable of such a crime? Whenever we hear of brawls and killings, we always see that our folk simply murder. But this is a sophisticated crime; it was not committed by a peasant hand: it must have been a Jewish hand at work. ${ }^{137}$

The court again gave a sentence of death by hanging, in the same order as the previous verdicts. Nowa Reforma condemned the falseness and use of emotions in the Vienna dailies' reports. ${ }^{138}$ The Vienna newspaper warned of the powerful influence of Rohling's writings, as Drzewicki apparently made use of his translation of the Talmud. He asked what the use of the defeat that Rohling experienced in the trial against Bloch was if the educated part of society continued to use dubious translations and books. ${ }^{139}$

\section{Revocation of the third death sentence}

The decision to revoke the sentence was taken at a plenary meeting headed by Stremayer, the second president of the Vienna Supreme Court. ${ }^{140}$ On the bidding of general advocate Simonowicz, the invalidity motion was rejected. However, owing to:

the numerous contradictions in the witnesses' testimonies and the baselessness of the evidence material presented, the Ritters were unanimously cleared of the crime of which they were accused, on the basis of para. 362 of the penal procedure. Following an injunction sent by the telegram from Vienna, the Cracow Tribunal released the Ritters from jail forthwith, and with cries of joy, the local Israelite population greeted them as they left the jail in which they had spent almost four years. ${ }^{141}$

The fact that crowds of their fellow Jews greeted the miraculously freed couple was referred to in all reports:

136 “Prozess Ritter,” Österreichische Wochenschrift 2 (1885), 38:3-4.

137 "Sprawy sądowe. Skrytobójcze morderstwo w Lutczy, Kraków, 29 września 1885," NR 4 (1885), 222:2; cf. "Prozess Ritter," Österreichische Wochenschrift 2.

138 "Sprawy sądowe. Skrytobójcze morderstwo w Lutczy, Kraków, 23 września,” NR 4 (1885), 214:2.

139 "Prozess Ritter," Österreichische Wochenschrift 2.

140 T., Gazeta Sądowa Warszawska za rok 1886 (1886), 14:208; "Kronika,” Czas 39 (1886), 53:2.

${ }^{141}$ Ibid.; "Kronika miejscowa i zamiejscowa. Uwolnienie Ritterów," Gazeta Narodowa 25 (1886), 53:2. 
At 5 in the afternoon [2 March], the presidium of the local court received an instruction by telegram from Vienna for the immediate release from prison of Mr. and Mrs. Ritter, accused of the murder in Lutcza. Informed of the actions of the Supreme Court by councillor Krzyżanowski, the Ritters reacted with elation and asked to be taken forthwith to their defense counsel, Dr. Rosenblatt. The people of Kazimierz, meanwhile, among whom the news had spread rapidly, gathered in numbers outside the prison building and accompanied the carriage with cries of joy. This infamous case thereby came to an end with a ruling for which the accused had been awaiting for four years (minus six days) in prison, sentenced to death three times by a jury verdict: in Rzeszów and then twice in Cracow. ${ }^{142}$

There were suspicions that, since nobody could have known of the ruling, the crowd must have gathered as a result of private telegrams sent from Vienna. This was interpreted as evidence of "Jewish solidarity" and powerful "Jewish influences." For the conservative Paweł Popiel, the Ritters' acquittal was proof that Jews "in courts benefit from impunity." 143

Moses and Gitla Ritter were acquitted and released from prison on 3 March 1886 at 6 a.m. ${ }^{144}$ An article about the release was published in the Vienna periodical Neuzeit. ${ }^{145}$ The same issue reported that Stochliński, having received the last rites on his deathbed in prison, confessed in the presence of the head of the court Czyszczan and the Regional Court councillor Krzyżanowski that the Ritters had not murdered Franciszka Mnichówna. ${ }^{146}$ This confession was not reported in any of the local newspapers-Galician or Cracovian—which I researched.

\section{The return to Lutcza}

As mentioned above, the Ritters returned to Lutcza. Again, they were accompanied to the station by a crowd of fellow Jews from Kazimierz. The couple also became an attraction in Rzeszów:

Crowds of Rzeszovians, mostly Jewish, filled the main market square on Tuesday the sixteenth of this month [March] to see the Ritters, who visited their former defense counsel Dr. Fechtdegen to thank him in person. ${ }^{147}$ $52: 2$.

142 “Kronika. Uwolnienie Ritterów,” NR 5 (1886), 52:2; also “Kronika,” Czas 39 (1886),

143 Popiel, Pamiętniki, 200.

144 Żyndul, Kłamstwo krwi, 156; "O uwolnieniu Ritterów. Kronika,” Dziennik Polski 19 (1886), 53:2.

145 "Noch gibt es Richter in Österreich," Neuzeit 26 (1886), 11:1.

146 "Kleine Kronik," Neuzeit 26 (1886), 11:104.

147 “Kronika," NR 5 (1886), 68:2. 
Unfortunately, I was unable to establish why the Ritters only thanked their Jewish lawyers, and not Dr. Maksymilian Machalski from Cracow or the notary Dr. Jan Pogonowski from Rzeszów, who also showed great dedication in defending them.

The couple therefore returned to Lutcza and continued to live with their neighbors, who during the trial had been convinced that ritual murder was something that existed and in which the Ritters were involved. We encounter the name Moses Ritter again in 1898 during a trial following the "largest wave of antisemitic disorder in nineteenth-century Galician history"148_ unrest, incidentally, which has in part been suppressed from Galician historical memory. ${ }^{149}$ During the disorder, the Ritter family home was broken into, and their property destroyed and looted. ${ }^{150}$

The Ritters' return to the family village, and even more so their continued existence in the old community, contradicts the arguments presented by Philip Friedman in his monograph published in 1928, today indispensable following the destruction of the sources cited by the author. Friedman wrote that the Jews living in the countryside did not engage in peasants' occupations, and only remained there as long as they felt safe. ${ }^{151}$ In the Ritters' case, neither the first nor the second part of this statement reflected reality.

\section{Remembrance}

Whereas the Ritter case is scarcely remembered at all in the "Polish" history of Galicia, it was passed on by "Jewish word of mouth." In legal terms, the case remained somewhat open, as Stochliński's final confession

148 Żbikowski, Żydzi krakowscy i ich gmina, 153, 292; Unowsky, The Plunder, 77.

149 The unrest of 1898 is not mentioned either by Jerzy Zdrada, Historia Polski 17951914 (Warsaw, 2005), or Andrzej Chwalba, Historia Polski 1795-1918 (Kraków, 2005). Andrzej Dziadzio goes as far as to assert that Galicia did not experience pogroms, and that the antisemitism it did experience was purely verbal; Andrzej Dziadzio, "Orzecznictwo austriackiego Trybunału Administracyjnego w sprawach wyznaniowych (1876-1918)," Czasopismo Prawno-Historyczne 47 (1995), 1-2:125f. (My thanks to Justyna Kasińska for making this article available to me.) The excesses of 1898 are mentioned in: Buchen, Antisemitismus in Galizien, 167-237; Soboń, Polacy wobec Żydów, 238-270; Frank Golczewski, Polnischjüdische Beziehungen 1881-1922: Eine Studie zur Geschichte des Antisemitismus in Osteuropa (Wiesbaden, 1981), 70-84; Kelly Stauter-Halsted, "Jews as Middleman Minorities in Rural Poland: Understanding the Galician Pogroms of 1898," in Robert Blobaum (ed.), Antisemitism and Its Opponents in Modern Poland (Ithaca-London, 2005), 39-59. The latest book by Daniel Unowsky analyzes specially this topic, see Unowsky The Plunder.

150 “Zizby sądowej (Rozruchy antysemickie), Rzeszów, 22 sierpnia,” NR 17 (1898), 191:3.

${ }^{151}$ Friedmann, Die galizischen Juden, 4. 
was reported only by Neuzeit, but the folk narrative concluded the "case" in a very interesting way. Strzyżów resident Itzhok Berglass recalled the Jewish peasant Itzhok Ritter, on whose field, hidden under manure, the body of a Ukrainian girl who served the local priest had been found. Ritter was accused of murdering the village woman and condemned first to death, and then to life imprisonment. Convinced of his innocence, his family approached Galician Jewish leaders, Rabbis Broide [Braude?] and Shmelkis [Schmelkes], who obtained an audience with the Emperor. This was attended by Ritter's daughter, two lawyers, the aforementioned rabbis, and also Rabbi Wilner, a family friend. As a result of the audience, Ritter was released, and soon afterward the priest confessed on his deathbed to having murdered the girl, who was pregnant with his child. It was he who had covered her body with manure. ${ }^{152}$

Here we have a list of popular themes which do not reflect the actual course of affairs: the good Kaiser, defender of Jews, ${ }^{153}$ the priest taking advantage of his prisoner, the Ukrainian servant girl and Jewish rabbis mentioned by name who defended Moses Ritter. The lawyers representing the modernized Jewry whom Ritter thanked in person remain anonymous, unlike the identified rabbinical authorities, who in fact did not play the role attributed to them.

Interestingly, Adam Węgłowski also used parts of this internet source to conclude his own "Ritter affair." His journalist, initially convinced of the guilt of the Jews, under the influence of an attractive proselyte moves to a pro-Jewish position, while Stochliński confesses on his deathbed that he murdered Mnichówna to protect the priest who was the father of her child. This all suggests that for the characters' descendants, the forgotten Ritter affair is not sensational enough, and lacks a spectacular conclusion. In the actual trial, the true murderer of Franciszka Mnichówna was not identified, nor was it proven whether she was murdered at all.

${ }^{152}$ Itzhok Berglass, "Strzyzow and its Inhabitants," in Itzhok Berglass, Shlomo Yahalomi-Diamand (eds.), The Book of Strzyzow and Vicinity (Tel Aviv, 1969), www.jewishgen.org/ yizkor/Strzyzow/str043.html [retrieved: 11 Dec. 2017].

${ }^{153}$ On the Kaiser as defender of peasants see Pieter M. Judson, Imperium Habsburgów. Wspólnota narodów, trans. Sławomir Patlewicz (Warsaw, 2016), 128; see also Unowsky, The Plunder, 81. 


\section{Conclusion}

What was really at stake with the Ritter affair? It seems unlikely that it was the accused themselves who were important, since they were hardly of particular interest to public opinion. The reason for the Ritter trial's infamy was the conducive atmosphere, fanned by the preceding Hungarian blood libels trials, as well as the accompanying Bloch-Röhling controversy, giving it the unwarranted notoriety. In Galicia, Teofil Merunowicz made an effort to instrumentalize the affair, using it in 1882 to "regulate the status of Jewish communities," which the Vienna government set about only in 1890. ${ }^{154}$ Merunowicz was attempting to control the parlous state that Galician jurisdiction was indeed in, of which Jews were themselves victims, for example when the validity of their ritual marriages was not recognized. ${ }^{155}$ Merunowicz's conclusions, which stressed the need for a change to the legal position of Jews, found support among his bitterest opponents, such as the Regional Assembly deputy Dr. Filip Zucker, "because the Josephine patent dated 1789 is certainly no longer appropriate today owing to the radically different conditions." 156 Merunowicz deviously connected an actual problem with the alleged existence of secretive Jewish law enshrined in books available only to Jews. As Zucker put it:

Anyone who believes that the Talmud and the Jewish religion prescribe atrocities, who believes that serving God means a series of sacrifices made to Molochs and Baals, who believes all this and reaches the conclusion of demanding reform of the Josephine patent, to me presents a psychological mystery. ${ }^{157}$

The Ritter affair, therefore, depending on its geographical breadth, was evaluated in various contexts and as serving various objectives. Yet it is important to note that it was thanks to this unwarranted notoriety assigned to the case outside of Galicia's borders that the Ritters were able to escape the death sentence to which successive local courts had condemned them. Without the insinuated analogies with the Hungarian blood libel and the Rohling trials going on at the time, the Ritters would

154 Dziadzio, Orzecznictwo austriackiego Trybunału Administracyjnego, 145-147.

${ }^{155}$ Numerous examples: Sprawozdanie. 6. posiedzenie 5. sesyi IV. peryodu Sejmu galicyjskiego z dnia 14 września 1882, pp. 67-69. Merunowicz failed to mention that the reason for the imprecision in records could also be the right of domicile law (swojszczyzna).

156 Sprawozdanie. 22. posiedzenie 5. sesyi IV. peryodu z dnia 10 października 1882, p. 427.

${ }^{157}$ Filip Zucker in ibid., p. 429; Mowa posta Dra Filipa Zukra wygłoszona w sprawie uregulowania prawnych stosunków ludności izraelickiej na posiedzeniu Sejmu krajowego z dnia 10 października 1882 (Lwów, 1882), 24. 
have been hanged after the Rzeszów trial. It was the "media storm" and the defense's approach that brought the case to the Vienna Tribunal, which ultimately quashed the Galician convictions.

What significance, if any, did the trial have for public opinion in Cracow? Above all, it was a diversion and sensation, especially as it combined the titillating elements of sex and crime. ${ }^{158}$ The form of the court reports alone differed from that of other press articles, including numerous descriptions and making extensive use of dialogue and emotions. The Warsaw-based Tygodnik Illustrowany, from the peaks of high arts, condemned the notoriety the trials had acquired:

On the streets of our city [Warsaw] one hears calls from all sides: "Terrible crime!", "Awful murder!". Where? What? Which? In Cracow. What could these exhortations mean? Why, ladies and gentlemen, that this terrible crime may be read about in some paper or another.

And thus Warsaw lives in this respect at the foot of great European cities. A press organ is advertised on the streets like matches, fruit, coal and similar everyday objects. Just a pity that they are advertised with regard to a terrible crime and awful murder.

We scrupulously read the description of a trial taking place in Cracow. What details, what minutiae, what shocking vividness! It is as if the salvation of mankind depended on these subtle little messages about how Stochliński struck Franka with an axe and the Ritters picked over her corpse. One needs strong nerves to read this all without disgust. But just wait... one can shake all this off. And slowly you will grow so accustomed to these minute descriptions that they will soon be like salt and pepper with your dinner. ${ }^{159}$

Press reports, especially from Czas, stressed the difference between a thorough trial and the sensational tone of reports in foreign newspapers, interpreting this as being to Galicia's benefit. This opinion was probably not only a major exaggeration, but simply false. Without doubt, the Ritter affair was a tempting morsel for the proliferation of competing newspapers that were springing up, which some readers saw as infallible oracles. Merunowicz, for example, cited the press as an authority and source of the truth: "It [alleged ritual murder] was written about in the

158 The significance of the problem is demonstrated by the fact that the Catholic Assembly of 1893 adopted the resolution to counteract the corrupting influence of the daily newspapers on less educated or minor readers by omitting detailed reports of judicial trials or descriptions of sensational cases, and leaving out details that might kindle base instincts; see Ksiega pamiatkowa wiecu katolickiego w Krakowie odbytego w dniach 4, 5 i 6 lipca 1893, ed. [Władysław] Chotkowski (Kraków, 1893), 228.

159 St. M. Rz., "Kronika tygodniowa," Tygodnik Illustrowany (1884), 93:231. 
dailies, and nobody denied it." 160 The falling rate of illiteracy and expanded political rates led to the emergence of the media as a "fourth state," which, somewhat unaccountably, enjoyed an unusual, unquestionable authority.

An almost perfect division in this respect could be identified between Jewish periodicals (against the accusations) and non-Jewish ones (accusing the Jews). The only newspaper that did not fit the bill was the liberal, Lviv-based Dziennik Polski, which assumed a neutral position. We can find this division in later historiographical tradition, as noted at the beginning of this article. Might we speak of the existence of two historical narratives which seldom, if ever, encountered each other in the media, operating in separate segments of public opinion? Both streams employed very similar elements, but they differed in their overall interpretation.

Some Jews regarded Ritter as a Galician martyr, and saw hope of justice only in the actions taken in distant Vienna. ${ }^{161}$ For Cracovian integrationist Jews, who were convinced of the Ritters' innocence, the trial and the verdict were a cause of shame and silence. In 1905 Dr. Józef Rosenblatt, the couple's defense counsel in Cracow and a specialist in judicial reviews, summarized his legal activity in a book on the subject of such reviews. ${ }^{162}$ Yet he did not mention the Ritter case, which is particularly surprising since he was involved in the trial itself, and discusses similar murder trials in the publication. As noted above, Rosenblatt criticized the unwarranted notoriety that the Ritter case attracted, perhaps fearing that the trial would embolden Galician antisemites and harm Jews. Other Cracow conservatives supported him in this view. ${ }^{163}$ I suspect that this position was also close to that of the Vienna rabbinate, which did not approve of the offensive position of Joseph S. Bloch and his active struggle against antisemitism. ${ }^{164}$ The rabbinate preferred to suppress the problem. ${ }^{165}$ The "extraordinary notoriety" referred to in this context meant the responsibility heaped on all

160 "Sejm. Sprawozdania sejmowe," Czas 35 (1882), 211:2; for a similar argument see Unowsky, The Plunder, 134.

161 “Der Schandfleck von Polna,” Sprawiedliwość - Die Gerechtigkeit 7 (1899), 16-18:2.

162 Józef Rosenblatt, Środek prawny rewizyi w procesie karnym (Kraków, 1905).

${ }^{163}$ Merunowicz wrote that: "Many believe that since trials on the Jewish question usually only incite passions, without achieving their objective, it would be better to avoid public debate on Jews." Merunowicz, Żydzi. Studyum społeczne, 6.

164 According to Harald Binder, by opposing Rohling, Bloch initiated a "modern Jewish politics," which emphasized the importance of Jewish identity, combined with Austrian patriotism, and fought against antisemitism. Harald Binder, Galizien in Wien: Parteien, Wahlen, Fraktionen und Abgeordnete im Übergang zur Massenpolitik (Wien, 2005), 156.

${ }^{165}$ Buchen, “'Herkules'," $193 \mathrm{f}$. 
Jews for a crime perhaps committed by just one. For non-Jewish readers, of course, the "notoriety" referred rather to the sensational charges, the course of the trial, the three revocations, and finally the release of the main accused parties.

It is difficult to assess how great an impact the Ritter case had on bolstering Galician and Cracovian antisemitism. The jury verdicts demonstrated the fact that city dwellers were inclined to view Jews as guilty in a circumstantial prosecution. The Cracow jurors were no different in this regard from their Rzeszów counterparts, who-according to press reports-were mostly ignorant and superstitious peasants. On the other hand, the case's renown meant that jurors could hardly be expected to be unbiased and independent in their judgements. The Ritter case can be viewed as one that was against all Jews. The widespread belief that the Jews were guilty, in spite of the contradictory evidence, does not depict Cracow's bourgeois elite, from which the jurors were recruited, in the best light. Based on the course of the trial, it also seems doubtful that Galician or Cracovian antisemitism was a mere product of economic competition.

There is no doubt that for the lawyers involved in the trial, the Ritter case was just one of many on which they worked, with no negative impact on their further careers. I was unable to infer what effect the questioned autopsy results had on the careers of the Cracow doctors, who, after all, were accused of making serious errors.

It is important to note that there were various reactions to the Ritter case in Galicia: whereas in Rzeszów in 1882 the publicity ensuing from it was regarded as a positive and an advertisement for the city, by 1884-1885 in Cracow no such advertisements were desired. The difference in reactions could be explained by the unwarranted notoriety that reinforced the perception of Galicia as a backward, unenlightened region, which was not to the taste of the Cracovian elites. The defense counsels thus also criticized the infallibility of vox populi referred to during the Rzeszów trial.

For me personally, this is a story about blurring of boundaries and the punishments faced by those who deliberately transgress them. In this case, people needed a reminder of these boundaries, as "rural" Jews were becoming increasingly similar to peasants, and the often cited "exclusivity between the population of the Mosaic faith and that of the Christian religion" was increasingly a question of wishful thinking. ${ }^{166}$ In an analysis of

166 Sprawozdanie. 22. posiedzenie 5. sesyi IV. peryodu z dnia 10 października 1882, p. 433. See also Andrzej Dziadzio, "Antysemityzm jako powód konfiskat prasowych. Orzecznictwo 
memoir literature, Heiko Haumann cites many examples of this increasing merging of traditionally distinct worlds in Galicia. ${ }^{167}$ And this was probably why Merunowicz was so determined to separate the two groups again, using the blood libel to do so. (As Zucker put it: "The honorable deputy laments that Jews hold a separate and exceptional position, and yet in the same breath aspires in civil, hereditary and marital matters, in the entirety of practical life, to provide them with a distinct position based on the Talmud." ${ }^{168}$ By finding the Jews guilty, the Galician vox populi hoped to restore the traditional boundaries and return the tested "right order." Execution of the accused would have been a symbolic catharsis.

What was surprising in the Ritter case was that reports failed to mention any antisemitic activities by peasant activists for whom accusing Ritter, as a representative of Jews, would be of benefit for consolidating their movement. Only the influence of local priests was mentioned. This probably indicates that the activity of priests in the countryside laid the groundwork for later antisemitism, which became an important component of politicized Catholicism in the version that would soon be represented by peasant movements.

Translated from Polish by Ben Koschalka

\section{Bibliography}

\section{Primary sources}

\section{Press}

Czas 1882-1886.

Dziennik Polski 1882-1886.

Gazeta Lwowska 1882-1885.

Gazeta Narodowa 1884-1886.

Gazeta Sadowa Warszawska za rok 18861886.

Kuryer Rzeszowski 1883-1886.

Neuzeit 1882-1886.

Nowa Reforma 1882-1886.

Österreichische Wochenschrift 1884-1886.

sądów krakowskich (XIX i XX w.)," in Grzegorz Górski, Leszek Ćwikła, Marzena Lipska (eds.), Cuius regio, eius religio? (Lublin, 2008), 2:215f.

${ }^{167}$ Heiko Haumann, "Juden in der ländlichen Gesellschaft Galiziens am Ende des 19. und zu Beginn des 20. Jahrhunderts," in id., Lebenswelten und Geschichte: Zur Theorie und Praxis der Forschung (Wien, 2012), 443-465.

${ }^{168}$ Sprawozdanie. 22. posiedzenie 5. sesyi IV. peryodu z dnia 10 października 1882, p. 430. 
Przegląd Rzeszowski 1883-1886.

Reforma 1882.

Sprawiedliwość - Die Gerechtigkeit 1899.

Tygodnik Illustrowany 1884-1886.

Unia. Dwutygodnik ekonomiczno-społeczny 1882.

\section{Other published sources}

Bałaban Majer, Dzieje Żydów w Galicyi i w Rzeczypospolitej krakowskiej 1772-1868 (Lwów, [n.d.]; reprint 1988).

Berglass Itzhok, "Strzyzow and its Inhabitants," in Itzhok Berglass, Shlomo Yahalomi-Diamand (eds.), The Book of Strzyzow and Vicinity [Sefer Strzyzow ve-ha-seviva], trans. Harry Langsam (Tel Aviv, 1969), www.jewishgen.org/ yizkor/Strzyzow/str043.html [retrieved: 11 Dec. 2017].

Bloch Joseph S., Erinnerungen aus meinem Leben (Wien-Leipzig, 1922), https:// archive.org/details/erinnerungenausm00blocuoft [retrieved: 17 Apr. 2018].

Bloch Joseph S., Professor Rohling und das Wiener Rabbinat oder "Die arge Schlemmerei" (Wien, 1882).

Ksiegga pamiatkowa wiecu katolickiego w Krakowie odbytego w dniach 4, 5 i 6 lipca 1893, ed. [Władysław] Chotkowski (Kraków, 1893).

Merunowicz Teofil, Siedem próśb wniesionych do Wysokiego Sejmu Krajowego galicyjskiego w sesyi z roku 1880 w sprawie równouprawnienia Żydów (Lwów, 1880).

Merunowicz Teofil, Żydzi. Studyum społeczne (Lwów, 1879).

[Mochnacki Józef], Rozprawa w procesie karnym Jana Matejki przeciw p. Dr.

L. E. [Leon Eibenschütz] o przestęstwo obrazy czci przeprowadzona w c.k. sadzie karnym w Krakowie, dnia 2-go grudnia 1882 (Kraków, 1883).

Popiel Paweł, Pamiętniki (1807-1892) (Kraków, 1927).

Rosenblatt Józef, Środek prawny rewizyi w procesie karnym (Kraków, 1905).

Sprawozdanie stenograficzne z rozpraw galicyjskiego Sejmu krajowego. 4. posiedzenie 5. sesyi IV. peryodu Sejmu galicyjskiego z dnia 11 września 1882, https://jbc.bj.uj. edu.pl/dlibra/publication/8720/edition/4469/content?\&ref=desc [retrieved: 18 Aug. 2018].

Sprawozdanie stenograficzne z rozpraw galicyjskiego Sejmu krajowego. 6. posiedzenie 5. sesyi IV. peryodu Sejmu galicyjskiego z dnia 14 września 1882, https://jbc.bj.uj. edu.pl/dlibra/publication/8722/edition/4471/content?\&ref=desc [retrieved: 18 Aug. 2018].

Sprawozdanie stenograficzne z rozpraw galicyjskiego Sejmu krajowego. 10. posiedzenie 5. sesyi IV. peryodu Sejmu galicyjskiego z dnia 21 września 1882, https://jbc.bj.uj. edu.pl/dlibra/publication/8727/edition/4492/content?ref=desc [retrieved: 18 Aug. 2018].

Sprawozdanie stenograficzne z rozpraw galicyjskiego Sejmu krajowego. 22. posiedzenie 5. sesyi IV. peryodu Sejmu galicyjskiego z dnia 10 października 1882, https://jbc. bj.uj.edu.pl/dlibra/publication/8746/edition/4527/content?\&ref=desc [retrieved: 18 Aug. 2018].

Żbikowski Andrzej, Dzieje Żydów w Polsce. Ideologia antysemicka 1848-1914. Wybór tekstów źródtowych (Warsaw, 1994). 
[Zucker Filip], Mowa posta Dra Filipa Zukra wygłoszona w sprawie uregulowania prawnych stosunków ludności izraelickiej na posiedzeniu Sejmu krajowego z dnia 10 października 1882 (Lwów, 1882).

\section{Secondary sources}

Avrutin Eugene M., Dekel-Chen Jonathan, Weinberg Robert et al. (eds.), Ritual Murder in Russia, Eastern Europe, and Beyond: New Histories of an Old Accusation (Bloomington, 2017).

Begg Paul, Jack the Ripper: The Facts (New York, 2013).

Binder Harald, Galizien in Wien: Parteien, Wahlen, Fraktionen und Abgeordnete im Übergang zur Massenpolitik (Wien, 2005).

Buchen Tim, Antisemitismus in Galizien: Agitation, Gewalt und Politik gegen Juden in der Habsburgermonarchie um 1900 (Berlin, 2012).

Buchen Tim, “'Herkules im antisemitischen Augiasstall' - Joseph Samuel Bloch und Galizien in der Reaktion auf Antisemitismus in der Habsburger Monarchie," in Ulrich Wyrwa (ed.), Einspruch und Abwehr: Die Reaktion des europäischen Judentums auf die Entstehung des Antisemitismus (1879-1914) (Frankfurt, 2010).

Cała Alina, Żyd - wróg odwieczny? Antysemityzm w Polsce i jego źródła (Warsaw, 2012).

Chwalba Andrzej, Historia Polski 1795-1918 (Kraków, 2005).

Cieśla Maria, Żyndul Jolanta, "Sprawa Ritterów. Aktualizacja legendy mordu rytualnego w Galicji końca XIX wieku," in Grażyna Borkowska, Magdalena Rudkowska (eds.), Kwestia żydowska w XIX wieku. Spory o tożsamość Polaków (Warsaw, 2004).

Derwich Marek (ed.), Pod zaborami 1795-1914 (Warsaw-Wrocław, 2005).

Dimolianis Spiro, Jack the Ripper and Black Magic: Victorian Conspiracy Theories, Secret Societies and the Supernatural Mystique of the Whitechapel Murders (Jefferson, 2011).

Dubnow Simon, Weltgeschichte des Jüdischen Volkes (Berlin, 1929), 10.

Dziadzio Andrzej, "Antysemityzm jako powód konfiskat prasowych. Orzecznictwo sądów krakowskich (XIX i XX w.)," in Grzegorz Górski, Leszek Ćwikła, Marzena Lipska (eds.), Cuius regio, eius religio? (Lublin, 2008), 2.

Dziadzio Andrzej, Monarchia konstytucyjna w Austrii 1867-1914. Władza-obywatel-prawo (Kraków, 2001).

Dziadzio Andrzej, "Orzecznictwo austriackiego Trybunału Administracyjnego w sprawach wyznaniowych (1876-1918)," Czasopismo Prawno-Historyczne 47 (1995), 1-2.

Friedmann Filip, “Dzieje Żydów w Galicji (1772-1914),” in Ignacy Schiper, Aryeh Tartakower, Aleksander Hafftka (eds.), Żydzi w Polsce odrodzonej. Działalność społeczna, gospodarcza, oświatowa i kulturalna (Warsaw, 1932).

Friedmann Philip, Die galizischen Juden im Kampfe um ihre Gleichberechtigung (1848-1868) (Frankfurt am Main, 1929).

Golczewski Frank, Polnisch-jüdische Beziehungen 1881-1922: Eine Studie zur Geschichte des Antisemitismus in Osteuropa (Wiesbaden, 1981). 
Grodziski Stanisław, W królestwie Galicji i Lodomerii (Kraków, 2005).

Hartston Barnet, Sensationalizing the Jewish Question: Anti-Semitic Trials and the Press in the Early German Empire (Leiden-Boston, 2005).

Haumann Heiko, "Juden in der ländlichen Gesellschaft Galiziens am Ende des 19. und zu Beginn des 20. Jahrhunderts," in id., Lebenswelten und Geschichte: Zur Theorie und Praxis der Forschung (Wien, 2012).

Judson Pieter M., Imperium Habsburgów. Wspólnota narodów, trans. Sławomir Patlewicz (Warsaw, 2016).

Kieval J. Hillel, “Tiszaeszlár,” in The YIVO Encyclopedia of Jews in Eastern Europe, 2010, https://yivoencyclopedia.org/article.aspx/Tiszaeszlar_Blood_Libel [retrieved: 20 Apr. 2018].

Kohlbauer-Fritz Gabriele (ed.), Zwischen Ost und West: Galizische Juden und Wien. Ausstellungskatalog (Wien, 2000).

Konstantynów Dariusz, “"Mistrz nasz Matejko’ i antysemici,” Kwartalnik Historii Żydów (2007), 2.

Kotliński Jakub, Kotliński Tomasz J., Sąownictwo powszechne w Galicji w latach 1855-1918 (Jarosław, 2016).

Kotliński Tomasz J., "Józef Fechtdegen,” in [A]dwokaci galicyjscy, http://kancelariajaroslaw.pl/adwokaci_galicyjscy.html [retrieved: 14 Jan. 2018].

Krawczyk Jarosław, Matejko i historia (Warsaw, 1990).

Manekin Rachel, "Galicia," trans. Deborah Weissman, in The YIVO Encyclopedia of Jews in Eastern Europe, http://www.yivoencyclopedia.org/article.aspx/Galicia [retrieved: 19 Jan. 2018].

Maner Hans-Christian, Galizien: Eine Grenzregion im Kalkül der Donaumonarchie im 18. und 19. Jahrhundert (München, 2007).

Meus Konrad, "Prasa prowincjonalna w badaniach nad miastami galicyjskimi doby autonomicznej. Geneza - charakterystyka -interpretacja," in Kazimierz Karolczak, Konrad Meus (eds.), Prasa w warsztacie badawczym historyka (Kraków, 2017).

Michalik Marian B. et al. (eds.), Kronika Krakowa (Warsaw, 1996).

Moszyński Maciej, Antysemityzm w Królestwie Polskim. Narodziny nowoczesnej ideologii antyżydowskiej (1864-1914) (Poznań, 2017).

Myśliński Jerzy, “Typologia,” in Jerzy Łojek (ed.), Prasa polska w latach 1864-1918 (Warsaw, 1976).

Salmonowicz Stanisław, Szwaja Janusz, Waltoś Stanisław, Pitaval krakowski, fifth edition (Kraków, 2010).

Soboń Marcin, Polacy wobec Żydów w Galicji doby autonomicznej w latach 1868-1914 (Kraków, 2011).

Stauter-Halsted Kelly, "Jews as Middleman Minorities in Rural Poland: Understanding the Galician Pogroms of 1898," in Robert Blobaum (ed.), Antisemitism and Its Opponents in Modern Poland (Ithaca-London, 2005).

Struve Kai, Bauern und Nation in Galizien: Über Zugehörigkeit und soziale Emanzipation im 19. Jahrhundert (Göttingen, 2005).

Tokarska-Bakir Joanna, Legendy o krwi. Antropologia przesadu (Warsaw, 2008). 
Unowsky Daniel, The Plunder: The 1898 Anti-Jewish Riots in Habsburg Galicia (Stanford, 2018).

Węgłowski Adam, Przypadek Ritterów (Katowice, 2012).

Węgrzynek Hanna, "Czarna legenda” Żydów. Procesy o rzekome mordy rytualne $w$ dawnej Polsce (Warsaw, 1995).

Widacki Jan, “Adwokat profesor Józef Rosenblatt i jego udział w krakowskim procesie Ludwika Waryńskiego i towarzyszy," Palestra 11-12 (2013), http:// palestra.pl/old/pdf_pliki/17_widacki_adwokat.pdf [retrieved: 21 Jan. 2018]. Wyrwa Ulrich, Die Internationalen Antijüdischen Kongresse von 1882 und 1883 in Dresden und Chemnitz: Zum Antisemitismus als europäischer Bewegung, https:// www.europa.clio-online.de/essay/id/fdae-1481 [retrieved: 20 Jan. 2018].

Żbikowski Andrzej, "Rozwój ideologii antysemickiej w Galicji w II połowie XIX w.: Teofila Merunowicza atak na żydowskie kahały,” Biuletyn Żydowskiego Instytutu Historycznego 169-171 (1994).

Żbikowski Andrzej, Żydzi krakowscy i ich gmina w latach 1869-1919 (Warsaw, 1995).

Zdrada Jerzy, Historia Polski 1795-1914 (Warsaw, 2005).

Zdrada Jerzy, "Machalski Maksymilian," in Polski Stownik Biograficzny (Wrocław, 1973), 18: http://www.ipsb.nina.gov.pl/a/biografia/maksymilian-machalski?print [retrieved: 21 Jan. 2018].

Żyndul Jolanta, Kłamstwo krwi. Legenda mordu rytualnego na ziemiach polskich w XIX i XX wieku (Warsaw, 2011).

Hanna Kozińska-Witt

Freelancer kozinska@web.de 